UDC 316.334: 614.253

DOI: $10.21668 /$ health.risk/2020.2.20.eng

\title{
OCCUPATIONAL HEALTH RISKS FOR DOCTORS IN CONTEMPORARY PUBLIC HEALTHCARE SYSTEMS (REVIEW)
}

\author{
I.L. Krom, M.V. Erugina, M.G. Eremina, E.P. Kovalev, \\ E.M. Dolgova, G.N. Bochkareva, E.A. Grigor'eva
}

Saratov State Medical University named after V.I. Razumovsky, 112 Bol'shaya Kazach'ya Str., Saratov, 410012, Russian Federation

Doctors' health is seen as a sign that a public healthcare system is efficient. Authors of the present work aimed to review occupational health risks for doctors in contemporary public healthcare systems; to do that, they analyzed publications taken from both domestic and foreign databases. Multiple research works indicate that doctors' health and their efficiency are closely connected with peculiarities of their working conditions. Literature contains convincing evidence that unfavorable working conditions exert their influence on doctors' health; induce occupational diseases, occupational stress and burnout. Specific attention paid to occupational burnout is due to its high prevalence as well as impacts exerted by it on individual health and occupational efficiency of doctors.

The authors note that researchers' interest to occupational stress occurs due to its negative effects on doctors' health and occupational efficiency and clinical safety as well. Some research works dwell on clinical context of occupational stress that includes strict requirements to work and adverse conditions that stimulate burnout and can result in a threat to a patient's safety. In researchers' opinion, specific development of occupational stress syndromes is predetermined by essence and peculiarities of occupational activities performed by doctors with different specialties. Prevalence of occupational burnout among doctors is associated with dysfunctional practices adopted in national public healthcare systems, conditions for medical aid provision, medical specialty, age and gender characteristics, and a stage in career development.

It is noted here that doctors' health is discussed in modern Russian research works not only within the context of unfavorable working conditions. An overall crisis and dysfunctional practices adopted in contemporary Russian public healthcare system have determined status inflation and marginalization of doctors' occupational group; it influences their individual health directly via financial deprivation and relative deprivation such as stress related to social comparison. In the authors' opinion, this stress ultimately results in occupational one.

Key words: health risks for doctors, risk factors, doctors' efficiency, occupational stress, unfavorable working conditions, burnout, status inflation, financial deprivation.

(c) Krom I.L., Erugina M.V., Eremina M.G., Kovalev E.P., Dolgova E.M., Bochkareva G.N., Grigor'eva E.A., 2020

Irina L. Krom - Doctor of Medical Sciences, Professor at the Department for Public Health and Healthcare (including courses in science of law and history of medicine) (e-mail: irina.crom@yandex.ru; tel.: +7 (917) 209-48-02; ORCID: https://orcid.org/0000-0003-1355-5163).

Marina V. Erugina - Doctor of Medical Sciences, Head of the Department for Public Health and Healthcare (including courses in science of law and history of medicine) (e-mail: lab48@yandex.ru; tel.: +7 (902) 040-35-75; ORCID: https://orcid.org/0000-0003-4253-5313).

Mariya G. Eremina - Candidate of Medical Sciences, a candidate for doctor degree at the Department for Public Health and Healthcare (including courses in science of law and history of medicine) (e-mail: 913693@mail.ru; tel.: +7 (927) 223-10-53; ORCID: https://orcid.org/0000-0001-9752-1352).

Evgenii P. Kovalev - post-graduate student at the Department for Public Health and Healthcare (including courses in science of law and history of medicine) (e-mail: kovalevevgeni2005@yandex.ru; tel.: +7 (937) 225-25-64; ORCID: https://orcid.org/0000-0002-7725-3036).

Elena M. Dolgova - Candidate of Medical Sciences, Associate Professor at the Candidate of Medical Sciences (e-mail: emdolgova@list.ru; tel.: +7 (905) 382-53-62; ORCID: https://orcid.org/0000-0002-0135-1254).

Galina N. Bochkareva - Senior lecturer at the Candidate of Medical Sciences (e-mail: bofrida@rambler.ru; tel.: +7 (927) 108-10-47; ORCID: https://orcid.org/0000-0003-1990-7182).

Ekaterina A. Grigor'eva - post-graduate student at the Department for Public Health and Healthcare (e-mail: vrach-katerina@mail.ru; tel.: +7 (937) 972-75-42; ORCID: https://orcid.org/0000-0002-8623-729X). 
Doctors' health is viewed as an integral part of their professional competence and as a parameter that shows efficiency of any public healthcare system $[1,2]$.

We analyzed publications from both domestic and foreign scientific, referential and full-text databases with our goal being to review health risk factors for doctors as a specific occupational group within public healthcare systems.

Multiple research works indicate that doctors' health and efficiency are closely connected with peculiarities of their working conditions. Literature sources give a lot of convincing evidence on impacts exerted by unfavorable occupational environment on doctors' health $[3,4]$.

Long working periods under great loads, time deficiency, extreme cognitive loads, and mental strain result in occupational stress which, in its turn, leads to individual's health deterioration [5-7]. According to P. Msaouel et al. [8] and A.A. Loerbroks et al. [9] prevalence of occupational stress among medical workers varies from 20 to $80 \%$. Prevalence equal to $57 \%$ was detected among doctors in Germany and Japan $[9,10]$ and $81 \%$ was detected for a mixed sampling that was made up of medical workers from various sections in a public healthcare system [11]. Authentic conclusions on occupational stress prevalence within national public healthcare systems are absent; it may be due to these systems as well as respondents' occupational profiles being different in different countries. There are also methodological differences that make it impossible to compare results obtained via examinations performed in different countries [11].

Researchers' interest in issues related to occupational stress comes from its obvious negative effects on doctors' health, their proficiency, and clinical safety $[12,13]$. A lot of research works dwell on clinical context of occupational stress that includes high requirements fixed for working tasks and adverse working conditions that make for burnout and threats to patients' safety. In researchers' opinion, specific development of occupational stress syndromes is determined by peculiar conditions in which doctors with various specialties actualize their occupational activities [14]. J. Siegrist et al. [15] view occupational stress as an imbalance between great efforts (great strain) and low compensations (for example, low salaries, no career prospects, no respect and no clinical safety); they also note that occupational stress potentially has grave negative outcomes.

Over decades research works devoted to occupational stress have been expanding and their contents have been transforming from focusing on some specific cases to determining the phenomenon as being «existential and common for those who have occupations determined as «helper» ones» [16].

Research works describe in detail what negative outcomes may result from occupational stress. Occupational stress may be considered an occupational burnout syndrome or it can have «various masked or somatic forms» [17]. Burnout becomes obvious via overwhelming exhaustion, depersonalization or cynicism towards colleagues, patients, and work as well as a feeling that one is losing his or her professional efficiency [18]. The research performed by W. Wurm et al. [19] revealed that burnout and deep depression coincided in their symptoms and deficiency of a three-dimensional concept of burnout. As R.T. Lee et al. [12] believe, special attention paid to burnout in multiple research works is due to its prevalence and influence on doctors' health and professional competence.

There are several reasons for burnout; some of them are personal traits, great occupational stress, and peculiarities related to management of a medical organization; however, psychosocial occupational stress was identified as the prevailing predictor of mental strain in doctors $[12,15,20,21]$.

Prevalence of burnout among doctors is related to dysfunctional practices accepted in national public healthcare systems, conditions for rendering medical aid, medical specialty, age and gender characteristics, and a stage in career development [17, 22-29]. 
Estimates given to burnout in different research works are ranked depending on measuring (exhaustion, depersonalization, or occupational inefficiency) and degree of burnout. Taking into account growing prevalence of burnout and the problem reaching «epidemic» levels, we can state that burnout can have devastating consequences for doctors, their colleagues, patients, and a public healthcare system as a whole [30-32].

Doctor's health is being discussed in contemporary Russian research works not only within the context of occupational risks that are relevant to adverse occupational conditions and induce occupational diseases, occupational stress, and occupational burnout. Risks for doctors' health in contemporary Russia are caused by changes in their occupational activities and institutionally determined peculiarities related to doctors' occupational self-fulfillment over the last decades due to socioeconomic transformations involving, among other things, the public healthcare system in the country [33].

Healthcare is a specific activity and its peculiarities are related to the fact that any social transformations induce changes in a public healthcare system; these changes create a new level of stress for occupational groups [34]. Multiple Russian research works indicate that institutional changes happening at the moment exert their influence on doctors' occupational activities, their contents and specificity.

An occupation as an attribute of healthcare as a social institute is a «key indicator of a status» [22]. There are research works where a medical occupation is proven to traditionally occupy the highest rank places in any occupational hierarchy $[35,36]$.

Over the last decades doctors' occupational activities have been becoming more and more complicated due to «multiple functions that doctors have to perform and intensified occupational loads» ${ }^{1}$. Social requirements to doctors are becoming higher, their activities are being regulated stricter, and their responsibilities are only growing [37].

Contemporary period in public healthcare institutionalization in Russia can be characterized only as a crisis [38]. A.V. Reshetnikov [22] sees a crisis in public healthcare in Russia as a social institution in 90ties last century and 10ties this century as its inverse development and characterizes the contemporary public healthcare institution as «paradoxical» with a lot of «antinomies», one of them being a contradiction between declared significance of a medical occupation and actual decline in prestige attributed to it. According to A.V. Reshetnikov, socially determined transformations that the public healthcare institution is undergoing now lead to changes in a status and role of contemporary public healthcare system in Russia and violate stability of social and occupational groups. I.P. Popova [39] characterizes dynamics of occupational groups in healthcare and states that there are changes in "social and occupational status and trends in social mobility».

R.G. Gromova [40] notes that social mobility in post-Soviet Russia in early 1990ties had some specific features and one of them was prevailing descending social mobility caused by declining social positions of certain social groups. Groups with descending social mobility «are on the periphery in any social development and are the most prone to marginalization» [41]. A crisis and dysfunctional practices that are intrinsic to contemporary public healthcare institution in Russia have predetermined inflation in social position and marginalization of doctors' occupational group [42].

Socioeconomic position is viewed as an obligatory predictor of a person's health [43]. A phenomenon that describes dependence between health and socioeconomic position is known as social gradient [44]. Research results indicate that there is a persistent correlation between one's socioeconomic position and health $[45,46]$. Low socioeconomic

\footnotetext{
${ }^{1}$ Okanina O.S. Transformation of doctors' occupational activities in a situation of the Russian society transition to market economy (basing on data collected in Buryatia): thesis for the ... Candidate of Social Sciences degree. Ulan-Ude, 2009, 26 p. (in Russian).
} 
position influences a person's health at an individual level directly via financial deprivations and indirectly via stresses caused by social comparison [47]. Besides, differences in health determined by socioeconomic position also occur due to unequal access to recourses that are significant for health preservation [48].

N.N. Sedova [49] gives a definition to «a specific social position of a doctor» and notes that doctors in Russia «are not satisfied with changes in their social position that occur in their occupational group. They are not satisfied either with their salaries or their working conditions». A.V. Reschetnikov, when considering a salary as a criterion of a doctor's social position, indicates that growing loads doctors have to face are not in line with a growth in their salaries $[22,50]$.

In contemporary Russia doctors are the least socially protected occupational group. Research conducted by I.L. Krom et al. [51] revealed that most doctors in the region estimated their living standard as low, and only $1.4 \%$ respondents stated they didn't face any financial deprivations.

Both foreign and domestic experience indicates that risks related to labor potential are most significant ones in public healthcare. Doctors' health as a predictor of growing availability and quality of medical aid predetermines success (or failure) in overcoming a crisis that contemporary public healthcare in Russia has to face. In relation to that it seems truly vital to perform research on issues and regularities related to development of labor potential in the public healthcare system and to develop mechanisms aimed at preserving its labor resources.

Funding. The research was not granted any sponsor support.

Conflict of interests. The authors declare there is no any conflict of interests.

\section{References}

1. Lesser C.S., Lucey C.R., Egener B., Braddock C.H., Linas S.L., Levinson W. A behavioral and systems view of professionalism. JAMA, 2010, vol. 304, no. 24, pp. 2732-2737. DOI: 10.1001/jama.2010.1864

2. Lemaire J.B., Wallace J.E. Burnout among doctors. BMJ, 2017, vol. 14, no. 358, pp. j3360. DOI: $10.1136 / \mathrm{bmj} . j 3360$

3. Leont'eva E.Yu., Bykovskaya T.Yu., Ivanov A.S. Current state of working and health conditions of health workers of dental speciality. Glavnyi vrach Yuga Rossii, 2019, vol. 67, no. 3, pp. 4-8 (in Russian).

4. Krasovskii V.O., Karamova L.M., Basharova G.R. Professional risks to health of the personnel of service of the first help. Norwegian Journal of Development of the International Science, 2019, vol. 26, no. 2, pp. 52-57 (in Russian).

5. Weigl M., Hornung S., Angerer P., Siegrist J., Glaser J. The effects of improving hospital physicians working conditions on patient care: a prospective, controlled intervention study. BMC Health Serv Res, 2013, no. 13, pp. 1. DOI: 10.1186/1472-6963-13-401

6. Kraatz S., Lang J., Kraus T., Münster E., Ochsmann E. The incremental effect of psychosocial workplace factors on the development of neck and shoulder disorders: a systematic review of longitudinal studies. Int. Arch. Occup. Environ. Health., 2013, no. 86, pp. 375-395. DOI: 10.1007/s0042 0-013-0848-y

7. Ma T., Yang T., Guo Y., Wang Y., Deng J. Do challenge stress and hindrance stress affect quality of health care? Empirical evidence from China. International journal of environmental research and public health, 2018, vol. 15, no. 8, pp. 1628. DOI: 10.3390/ijerph15081628

8. Msaouel P., Keramaris N.C., Apostolopoulos A.P., Syrmos N., Kappos T., Tasoulis A., Tripodaki E.-S., Kagiampaki E. [et al.]. The effort reward imbalance questionnaire in Greek: translation, validation and psychometric properties in health professionals. J. Occup. Health., 2012, no. 54, pp. 119-130. DOI: 10.1539/joh.11-0197-OA

9. Loerbroks A., Weigl M., Li J., Angerer P. Effort-reward imbalance and perceived quality of patient care: a cross-sectional study among physicians in Germany. BMC Public Health, 2016, vol. 18, no. 16, pp. 342. DOI: $10.1186 / \mathrm{s} 12889-016-3016-\mathrm{y}$ 
10. Tsutsumi A., Kawanami S., Horie S. Effort-reward imbalance and depression among private practice physicians. Int. Arch. Occup. Environ. Health., 2012, no. 85, pp. 153-161. DOI: 10.1007/s0042 0-011-0656-1

11. Vu-Eickmann P., Li J., Mueller A., Angerer P., Loerbroks A. Associations of psychosocial working conditions with health outcomes, quality of care and intentions to leave the profession: results from a cross-sectional study among physician assistants in Germany. International archives of occupational and environmental health, 2018, vol. 91, no. 5, pp. 643-654. DOI: 10.1007/s00420-018-1309-4

12. Lee R.T., Seo B., Hladkyj S., Lovell B.L., Schwartzmann L. Correlates of physician burnout across regions and specialties: a meta-analysis. Hum. Resour. Health., 2013, no. 11, pp. 48. DOI: $10.1186 / 1478-4491-11-48$

13. Lepaev Yu.V. Clinical Sign of Emotional Stress in Neurologists. Vestnik Meditsinskogo stomatologicheskogo instituta, 2018, vol. 45, no. 2, pp. 31-36 (in Russian).

14. Nesyn V.V., Nesyna S.V. Burnout of health professionals. Zdorov'e i obrazovanie $v$ XXI veke, 2019, vol. 21, no. 6, pp. 19-23 (in Russian).

15. Siegrist J., Shackelton R., Link C., Marceau L., Vondem Knesebeck O., McKinlay J. Work stress of primary care physicians in the US, UK and German health care systems. Soc. Sci. Med., 2010, vol. 71, no. 2, pp. 298-304. DOI: 10.1016/j.socscimed.2010.03.043

16. Nerush T.G. Main Stages of Studying the Burnout Phenomenon. Izvestiya Saratovskogo universiteta. Seriya: Filosofiya. Psikhologiya. Pedagogika, 2017, vol. 17, no. 4, pp. 454-459 (in Russian).

17. West C.P., Dyrbye L.N., Erwin P.J., Shanafelt T.D. Interventions to prevent and reduce physician burnout: a systematic review and meta-analysis. Lancet, 2016, vol. 388, no. 10057, pp. 2272-2281. DOI: 10.1016/S0140-6736(16)31279-X

18. Maslach C., Leiter M.P. Understanding the burnout experience: recent research and its implications for psychiatry. World Psychiatry, 2016, vol. 15, no. 2, pp. 103-111. DOI: 10.1002/wps.20311

19. Wurm W., Vogel K., Holl A., Ebner C., Bayer D., Mörkl S., Szilagyi I.-S., Hotter E. [et al.]. Depression-burnout overlap in physicians. Plos One, 2016, vol. 11, no. 3, pp. e0149913. DOI: 10.1371/journal.pone.0149913

20. Linzer M., Poplau S., Babbott S., Collins T., Guzman-Corrales L., Menk J., Murphy M.L., Ovington $\mathrm{K}$. Worklife and wellness in academic general internal medicine: results from a national survey. J. Gen. Intern. Med., 2016, vol. 31, no. 9, pp. 1004-1010. DOI: 10. 1007/s11606-016-3720-4

21. Sorokin G.A., Suslov V.L., Yakovlev E.V., Frolova N.M. Professional burnout in doctors: the value of the intensity and quality of the work. Gigiena $i$ sanitariya, 2018, vol. 97, no. 12, pp. 1221-1225 (in Russian).

22. Reshetnikov A.V. The social institution of medicine. Part II. Sotsiologiya meditsiny, 2018, vol. 17, no. 2, pp. 68-79 (in Russian). DOI: 10.18821/1728-2810-2018-17-2-68-79

23. Kumar S. Burnout and doctors: prevalence, prevention and intervention. Healthcare (Basel), 2016, vol. 43, no. 4 (3), pp. 37. DOI: 10.3390/healthcare4030037

24. Kobyakova O.S., Deev I.A., Kulikov E.S., Pimenov I.D., Khomyakov K.V. Burnout in doctors and medical errors. Is there a connection? Sotsial'nye aspekty zdorov'ya naseleniya, 2016, vol. 47, no. 1, pp. 5 (in Russian).

25. Netesin E.S., Gorbachev V.I., Nelyubin A.G., Mitkinov O.E. Burnout syndrome in anesthesiologists and intensive care physicians. Acta Biomedica Scientifica, 2017, vol. 2, no. 1 (113), pp. 74-78 (in Russian).

26. Styazhkina S.N., Demina M.A., Chernysheva T.E., Belousova O.A., Shestakova A.P., Shirobokova A.P. Sindrom emotsional'nogo vygoraniya kak bar'er professional'noi samorealizatsii vrachei-khirurgov [Emotional burnout syndrome as a barrier to occupational self-realization of surgeons]. Tavricheskii nauchnyi obozrevatel', 2017, vol. 21, no. 4-1, pp. 100-101 (in Russian).

27. Yuguero O., Forné C., Esquerda M., Pifarré J., Abadías M.J., Viñas J. Empathy and burnout of emergency professionals of a health region: across-sectional study. Medicine (Baltimore), 2017, vol. 96, no. 37, pp. e8030. DOI: 10.1097/MD.0000000000008030 
28. Vasil'eva I.V., Grigor'ev P.E. Features of emotional burnout of physicians depending on work experience. Tavricheskii zhurnal psikhiatrii, 2017, vol. 21, no. 1 (78), pp. 21-27 (in Russian).

29. Lee R.T., Seo B., Hladkyj S., Lovell B.L., Schwartzmann L. Correlates of physician burnout across regions and specialties: a meta-analysis. Human Resources for Health, 2013, no. 11, pp. 48. DOI: 10.1186/1478-4491-11-48

30. Rotenstein L.S., Matthew T., Marco M.A., Rosales R.S., Guille C., Sen S., Mata D.A. Prevalence of burnout among physicians: a systematic review. JAMA, 2018, vol. 320, no. 11, pp. 1131-1150. DOI: 10.1001/jama.2018.12777

31. Panagioti M., Panagopoulou E., Bower P., Lewith G., Kontopantelis E., Chew-Graham C., Dawson S., Van Marwijk H. [et al.]. Controlled interventions to reduce burnout in physicians: a systematic review and meta-analysis. JAMA. Intern Med, 2017, vol. 177, no. 2, pp. 195-205. DOI: $10.1001 /$ jamainternmed.2016.7674

32. Dyrbye L., Shanafelt T. A narrative review on burnout experienced by medical students and residents. Med. Educ., 2016, vol. 50, no. 1, pp. 132-149.DOI: 10.1111/medu.12927

33. Semina T.V. Social conflict «doctor-patient» in modern Russian society: the objective reasons and subjective factors. Vestnik Moskovskogo universiteta. Seriya 18: sotsiologiya i politologiya, 2016, vol. 22, no. 1, pp. 84-106 (in Russian).

34. Ivchenkova M.S. Modernization of Public Health Care in Russia and in the Region: Sociological Overview. Izvestiya Saratovskogo universiteta. Seriya: Sotsiologiya. Politologiya, 2013, vol. 13, no. 3, pp. 41-43 (in Russian).

35. Freeland R.E., Hoey J. The Structure of deference: modeling occupational status using affect control theory. American Sociological Review, 2018, vol. 83, no. 2, pp. 243-277. DOI: $10.1177 / 0003122418761857$

36. Kleinjans K.J., Krasse, K.F., Dukes A. Occupational prestige and the gender wage gap. Kyklos, 2017, vol. 70, no. 4, pp. 565-593. DOI: 10.1111/kykl.12149

37. Reshetnikov A.V. Sovremennye podkhody k otsenke vzaimootnoshenii mezhdu patsientom i vrachom, meditsinskoi organizatsiei, strakhovoi meditsinskoi organizatsiei [Contemporary approaches to assessing relations between a patient and a doctor, medical organizations, and medical insurance company]. Sotsial'naya rol' vracha $v$ Rossiiskom obshchestve: materialy Vserossiiskoi nauchno-prakticheskoi konferentsii. Nizhnii Novgorod, 2018, pp. 1-3 (in Russian).

38. Shchepin O.P., Korotkikh R.V. The perspectives of development of health care of the Russian Federation. Problemy sotsial'noi gigieny, zdravookhraneniya i istorii meditsiny, 2015, vol. 23, no. 6, pp. 3-6 (in Russian).

39. Popova I.P. Novye marginal'nye gruppy v rossiiskom obshchestve (teoreticheskie aspekty issledovaniya) [New marginal groups in the Russian society (theoretical aspects of the research)]. Sotsiologicheskie issledovaniya, 1999, no. 7, pp. 62-71 (in Russian).

40. Gromova R.G. Sotsial'naya mobil'nost' v Rossii: 1985-1993 gody [Social mobility in Russia: 1985-1993]. Sotsiologicheskii zhurnal, 1998, no. 1-2, pp. 15-38 (in Russian).

41. Razinskii G.V., Slyusaryanskii M.A. The groups of descending social mobility and the market: specificity of integration. Vestnik Permskogo natsional'nogo issledovatel'skogo politekhnicheskogo universiteta. Sotsial'no-ekonomicheskie nauki, 2011, no. 10, pp. 11-30 (in Russian).

42. Krom I.L., Erugina M.V., Kovalev E.P., Eremina M.G., Vlasova M.V., Dolgova E.M., Bochkareva G.N. Marginalization of health institute professional groups: societal approach. Saratovskii nauchno-meditsinskii zhurnal, 2017, vol. 13, no. 4, pp. 854-856 (in Russian).

43. Zang E., Bardo A.R. Objective and subjective socioeconomic status, their discrepancy, and health: evidence from East Asia. Social indicators research, 2019, vol. 143, no. 2, pp. 765-794. DOI: $10.1007 / \mathrm{s} 11205-018-1991-3$

44. Nedospasova O.P., Shibalkov I.P. Socioeconomic status (ses) of a person as a health factor. Azimut nauchnykh issledovanii: ekonomika i upravlenie, 2017, vol. 6, no. 1 (18), pp. 140-144 (in Russian).

45. Pastukhova E.Ya. Material welfare as a factor of influence on the population health in Russian regions. Obshchestvo: politika, ekonomika, pravo, 2017, no. 8, pp. 38-41 (in Russian). 
46. Wang J., Geng L. Effects of socioeconomic status on physical and psychological health: lifestyle as a mediator. International journal of environmental research and public health, 2019, vol. 16, no. 2, pp. 281. DOI: 10.3390/ijerph16020281

47. Pastukhova E.Ya., Morozova E.A. Poverty as a risk factor for population health in the regions. Mezhdunarodnyi zhurnal prikladnykh i fundamental'nykh issledovanii, 2017, vol. 3, no. 2, pp. 253-257 (in Russian).

48. Rusinova N.L., Safronov V.V. The issue of social inequality in terms of health: a comparative study of Russia within the European context. Vestnik Instituta sotsiologii, 2019, vol. 10, no. 1, pp. 139-161 (in Russian).

49. Sedova N.N., Vargina S.A. Sotsial'nye riski rasprostraneniya «meditsinskogo imperializma» v postsovetskoi Rossii [Social risks of «medical imperialism» spread in post-Soviet Russia]. Izvestiya VolgGTU, 2010, vol. 7, no. 7, pp. 38-42 (in Russian).

50. Reshetnikov A.V. Sotsiologiya meditsiny [Sociology of medicine]. Moscow, 2010, 864 p. (in Russian).

51. Krom I.L., Erugina M.V., Kovalev E.P., Eremina M.G., Bochkareva G.N. The quality of life of physicians in the contest of financial deprivations. Sotsiologiya meditsiny, 2018, vol. 17, no. 2, pp. 80-82 (in Russian). DOI: 10.18821/1728-2810-2018-17-2-80-82

Krom I.L., Erugina M.V., Eremina M.G., Kovalev E.P., Dolgova E.M., Bochkareva G.N., Grigor'eva E.A. Occupational health risks for doctors in contemporary public healthcare systems (review). Health Risk Analysis, 2020, no. 2, pp. 185-191. DOI: 10.21668/health.risk/2020.2.20.eng

Received: 05.12.2019

Accepted: 03.06.2020

Published: 30.06 .2020 